\title{
Front Matter: Volume 10647
}

, "Front Matter: Volume 10647," Proc. SPIE 10647, Algorithms for Synthetic Aperture Radar Imagery XXV, 1064701 (21 May 2018); doi:

$10.1117 / 12.2501432$

SPIE. Event: SPIE Defense + Security, 2018, Orlando, FL, United States 


\title{
PROCEEDINGS OF SPIE
}

\section{Algorithms for Synthetic Aperture Radar Imagery XXV}

\author{
Edmund Zelnio \\ Frederick D. Garber \\ Editors
}

19 April 2018

Orlando, Florida, United States

Sponsored and Published by

SPIE 
The papers in this volume were part of the technical conference cited on the cover and title page. Papers were selected and subject to review by the editors and conference program committee. Some conference presentations may not be available for publication. Additional papers and presentation recordings may be available online in the SPIE Digital Library at SPIEDigitallibrary.org.

The papers reflect the work and thoughts of the authors and are published herein as submitted. The publisher is not responsible for the validity of the information or for any outcomes resulting from reliance thereon.

Please use the following format to cite material from these proceedings:

Author(s), "Title of Paper," in Algorithms for Synthetic Aperture Radar Imagery XXV, edited by Edmund Zelnio, Frederick D. Garber, Proceedings of SPIE Vol. 10647 (SPIE, Bellingham, WA, 2018) Seven-digit Article CID Number.

ISSN: 0277-786X

ISSN: 1996-756X (electronic)

ISBN: 9781510618053

ISBN: 9781510618060 (electronic)

Published by

SPIE

P.O. Box 10, Bellingham, Washington 98227-0010 USA

Telephone +1 3606763290 (Pacific Time) · Fax +1 3606471445

SPIE.org

Copyright (C) 2018, Society of Photo-Optical Instrumentation Engineers.

Copying of material in this book for internal or personal use, or for the internal or personal use of specific clients, beyond the fair use provisions granted by the U.S. Copyright Law is authorized by SPIE subject to payment of copying fees. The Transactional Reporting Service base fee for this volume is $\$ 18.00$ per article (or portion thereof), which should be paid directly to the Copyright Clearance Center (CCC), 222 Rosewood Drive, Danvers, MA 01923. Payment may also be made electronically through CCC Online at copyright.com. Other copying for republication, resale, advertising or promotion, or any form of systematic or multiple reproduction of any material in this book is prohibited except with permission in writing from the publisher. The CCC fee code is 0277 $786 \mathrm{X} / 18 / \$ 18.00$.

Printed in the United States of America.

Publication of record for individual papers is online in the SPIE Digital Library.

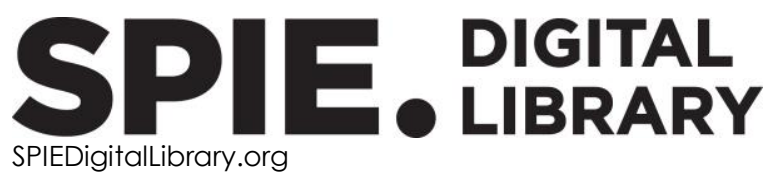

Paper Numbering: Proceedings of SPIE follow an e-First publication model. A unique citation identifier (CID) number is assigned to each article at the time of publication. Utilization of CIDs allows articles to be fully citable as soon as they are published online, and connects the same identifier to all online and print versions of the publication. SPIE uses a seven-digit CID article numbering system structured as follows:

- The first five digits correspond to the SPIE volume number.

- The last two digits indicate publication order within the volume using a Base 36 numbering system employing both numerals and letters. These two-number sets start with 00, 01, 02, 03, 04, $05,06,07,08,09,0 A, 0 B \ldots$ OZ, followed by 10-1Z, 20-2Z, etc. The CID Number appears on each page of the manuscript. 


\title{
Contents
}

\author{
$\checkmark \quad$ Authors \\ vii Conference Committee
}

\section{SYNTHETIC DATA AND DEEP LEARNING}

1064702 AFacet: a geometry based format and visualizer to support SAR and multisensor signature generation [10647-1]

1064703 High performance computing strategies for SAR image experiments [10647-2]

1064708 Mobile high-performance computing (HPC) for synthetic aperture radar signal processing [10647-7]

1064709 Generative adversarial networks for SAR image realism [10647-8]

10647 OA Blending synthetic and measured data using transfer learning for synthetic aperture radar target classification [10647-9]

10647 OB Deep learning model-based algorithm for SAR ATR [10647-10]

10647 OC Development of Convolutional Neural Networks (CNNs) for feature extraction [10647-11]

10647 OD Using deep learning for SAR image optimization [10647-12]

10647 OE Deep learning for waveform estimation in passive synthetic aperture radar imaging [10647-13]

ADVANCED IMAGE FORMATION, 3D RECONSTRUCTION, AND MOVING TARGET EXPLOITATION

10647 OF SAR processing UWB VHF data without a motion measurement system [10647-14]

10647 OG Sparsity-driven coupled imaging and autofocusing for interferometric SAR [10647-15]

$10647 \mathrm{OH} \quad$ Leveraging 3D models for SAR-based navigation in GPS-denied environments [10647-16]

10647 Ol Three-dimensional total least square Prony method for 3D synthetic aperture scatterer localization [10647-17]

10647 OJ Sparse 4D TomoSAR imaging in the presence of non-linear deformation [10647-18] 
10647 OK A subaperture based approach for SAR moving target imaging by low-rank and sparse decomposition [10647-19]

$10647 \mathrm{OL}$ Insights into the complicated SAR signature shapes induced by braking targets [10647-20]

10647 OP Synthetic aperture radar quantized grayscale reference automatic target recognition algorithm [10647-24]

10647 OR Variance based joint sparsity reconstruction of synthetic aperture radar data for speckle reduction [10647-27] 


\section{Authors}

Numbers in the index correspond to the last two digits of the seven-digit citation identifier (CID) article numbering system used in Proceedings of SPIE. The first five digits reflect the volume number. Base 36 numbering is employed for the last two digits and indicates the order of articles within the volume. Numbers start with 00, 01, 02, 03, 04, 05, 06, 07, 08, 09, OA, OB...0Z, followed by 10-1Z, 20-2Z, etc.

Åhlander, Anders, OF Arnold, Julia M., OA

Ash, Joshua N., $\mathrm{OH}$

Çetin, Müjdat, OG, OJ, OK

Dammert, Patrik, OF

Eikmeier, Nicole, OC

Friedlander, Robert D., OB

Garren, David A., OL

Gelb, Anne, OR

Hellsten, Hans, OF

John-Baptiste, Peter, OD

Kaufhold, John, 03

Khwaja, Ahmed Shaharyar, OG, OJ, OK

Kim, Youngsoo, 08

Levy, Michael, OB

Lewis, Benjamin, 09

Lewis, Travious, OP

Liu, Jennifer, 09

Mason, Eric, $\mathrm{OE}$

Misko, Joshua, 08

Moore, Linda J., OA

Nehrbass, John, 02

Paulson, Christopher, OP

Pepin, Matthew, 01

Qi, Chenchen, 08

Reid, Zachary, $\mathrm{OH}$

Rosencrantz, Stephen, 02

Saville, Michael A., 03

Scarnati, Theresa, OR

Short, David F., 03

Sirkeci, Birsen, 08

Smith, Graeme E., OD

Sudkamp, Elizabeth, 02, OB

Torgrimsson, Jan, $\mathrm{OF}$

Trammell, Jeremy, 03

Ulander, Lars M. H., OF

Westerkamp, Rachel, OC

Wilson, Jervon, OP

Wong, Amy, 09

Yasin, Mubashar, OK

Yazici, Birsen, OE

Yonel, Bariscan, $\mathrm{OE}$

Zelnio, Edmund G., O2, OA, OB, OC, OD

Zengin, Oğuzcan, OG 
Proc. of SPIE Vol. 10647 1064701-6

Downloaded From: https://www.spiedigitallibrary.org/conference-proceedings-of-spie on 26 Apr 2023 Terms of Use: https://www.spiedigitallibrary.org/terms-of-use 


\section{Conference Committee}

Symposium Chair

Arthur A. Morrish, Raytheon Space and Airborne Systems

(United States)

Symposium Co-chair

Ruth L. Moser, Air Force Research Laboratory (United States)

Conference Chairs

Edmund Zelnio, Air Force Research Laboratory (United States)

Frederick D. Garber, Wright State University (United States)

Conference Program Committee

Joshua N. Ash, Wright State University (United States)

David Blacknell, Defence Science and Technology Laboratory

(United Kingdom)

Mujdat Cetin, Sabanci University (Turkey)

Gil J. Ettinger, Systems \& Technology Research (United States)

David A. Garren, Naval Postgraduate School (United States)

Eric R. Keydel, Leidos, Inc. (United States)

Juan Li, University of Central Florida (United States)

Uttam Kumar Majumder, Air Force Research Laboratory

(United States)

Michael J. Minardi, Air Force Research Laboratory (United States)

Randolph L. Moses, The Ohio State University (United States)

Les Novak, Scientific Systems Company, Inc. (United States)

Christopher Paulson, Air Force Research Laboratory (United States)

Lee C. Potter, The Ohio State University (United States)

Brian Rigling, Wright State University (United States)

Timothy D. Ross, Jacobs Technology (United States)

Session Chairs

1 Synthetic Data and Deep Learning

Christopher R. Paulson, Air Force Research Laboratory (United States)

2 Advanced Image Formation, 3D Reconstruction, and Moving Target

Exploitation

Uttam Kumar Majumder, Air Force Research Laboratory

(United States) 
Proc. of SPIE Vol. 10647 1064701-8

Downloaded From: https://www.spiedigitallibrary.org/conference-proceedings-of-spie on 26 Apr 2023 Terms of Use: https://www.spiedigitallibrary.org/terms-of-use 